УДК 391(=511.1):391(=512.1)

\title{
Е. Е. Нечвалода
}

\author{
НАРОДЫ ВОЛГО-УРАЛЬСКОГО РЕГИОНА \\ В ТВОРЧЕСКОМ НАСЛЕДИИ ФЕДОРА СОЛНЦЕВА ${ }^{1}$
}

Статья посвящена исследованию изображений народов Волго-Уральского региона в графике художникаакварелиста XIX в. Федора Григорьевича Солнцева, автора многих исторических реконструкций и этнографических зарисовок народного костюма различных губерний России. В галерее образов, созданных художником, изображения народов Волго-Уральского региона: удмуртов, марийцев, мордвы, чувашей, татар. Если многие акварели Ф. Г. Солнцева, запечатлевшие этнографические типажи, были выполнены с натурных зарисовок, то основой его изображения представителей народов Волго-Уральского региона явились иные, визуальные материалы. Так, первоисточниками для Ф. Г. Солнцева выступили гравюры Е. М. Корнеева (при создании образа «вотячки»), фотографии В. Каррика (как основа для некоторых изображений «казанских татар») и картина неизвестного непрофессионального художника конца XVIII - начала XIX вв. (при создании композиций «черемисы»). Вероятно, именно это обстоятельство (использование чужих готовых образцов, а не собственных этнографических зарисовок) привело к появлению некоторых неточностей и в изображениях костюмных комплексов народов Волго-Уральского региона, исполненных Ф. Г. Солнцевым, и в аннотациях к ним. Прототипы изображений марийцев и мордвы Ф. Г. Солнцева пока не найдены; но отсутствие этнической атрибуции в аннотациях к ним, неточности в их географической привязке, ошибки в изображении деталей костюма мордвы, определенное несоответствие поз, в которых они запечатлены; а также ракурсам, характерным для «натурных» этнических типажей Ф. Г. Солнцева, - дают основание предположить, что его образы марийцев и мордвы (на листах «Пензенской» и «Тамбовской губернии») тоже скопированы художником с готовых изображений.

Ключевые слова: традиционный костюм, народы Волго-Уральского региона, визуальные образы, графика XIX в., атрибуция источника, Ф. Г. Солнцев, Е. М. Корнеев, В. Каррик, визуальная антропология.

DOI: $10.35634 / 2224-9443-2020-14-4-720-732$

Первые из известных нам графических изображений народов Волго-Уральского региона были созданы в XVI-XVII вв. (С. Герберштейном, А. де Брейном, А. Олеарием, художником посольства А. Мейерберга). В XVIII в. круг визуальных образов народов Урало-Поволжья был значительно расширен работой на территории Российской империи многих исследовательских экспедиций, маршруты которых пролегали через территории проживания этносов обозначенного региона. В отличие от первых одиночных и не очень подробных изображений предыдущих веков, материалы академических экспедиций запечатлели традиционные костюмы всех народов рассматриваемого региона (и даже их варианты: у мордвы - эрзянский и мокшанский; у марийцев - комплекс с шуркой и комплекс с шымакшем; иногда в иллюстрациях к «путеше-

${ }^{1}$ Статья выполнена в рамках государственного задания ИЭИ УФИЦРАН «Этнические культуры старожильческого населения и переселенцев на Южном Урале в условиях села и города» (АААА-А18-118041290047-7). 
ствиям» был представлен не только женский, но и девичий наряд). В ряде случаев на гравюрах XVIII в. этнические типажи изображены в нескольких ракурсах, чтобы полнее отразить особенности их одежд. Как правило, визуальные материалы экспедиций XVIII в. не были отмечены техническим и художественным совершенством; их главная задача - быть максимально информативными в этнографическом плане. Графическим образам XVI-XVIII вв., как источнику по истории традиционного костюма народов Волго-Уральского региона, посвящен ряд статей [Гатина-Шафикова 2014, 2014 а; Мазанов 1982; Нечвалода 2014, 2016, 2019 и др.].

B XIX в. графических материалов, отражающих особенности традиционного костюма народов Урало-Поволжья, становятся еще больше. И среди них появляются работы, интересные не только этнографически, но и в художественном отношении.

С именем Федора Солнцева связана особая страница в истории изобразительных искусств России XIX в. Художник-историк, создавший целую галерею исторических образов, графических реконструкций одежд и доспехов, посвятивший всю жизнь восстановлению историкокультурных памятников и визуальной фиксации исторических артефактов, Федор Солнцев любил и изучал историю Отечества: самобытные национальные традиции в культуре; стремился доступными ему средствами увековечить культурное наследие, принадлежащие не только историческому прошлому, но и этнографической (для него) современности. Федор Солнцев был не только художником-историком и реконструктором; с полным правом его можно назвать художникомэтнографом как автора большой серии работ, отразивших особенности традиционного русского костюма различных губерний. Для этнографии они весьма точны и бесценны, т.к. большинство их представляют собою документы «дофотографической» эпохи. Прорисовки исторического костюма и современных ему этнографических типов как представителей разных сословий вошли в подготовленный им альбом «Одежды русского государства» $(1869$ г.). Интерес к этнографии, крестьянской культуре у Ф. Г. Солнцева не случаен. Он родился в семье крепостного крестьянина, которого вместе с семьей освободили от зависимости благодаря одаренности его сыновей. Федор Солнцев получил образование в Академии художеств, а впоследствии - звание академика. Он был «связан корнями» с крестьянским миром: чувствовал его, ценил традиционный народный костюм во всем его прихотливом многообразии и великолепии. Вероятно, многим выпускникам Академии художеств, воспитывавшимся исключительно на совершенных, но холодных и чужих античных образах, на канонах классицизма, такое видение было недоступно. Среди «этнографических» листов Ф. Г. Солнцева, помимо русских типажей в различных костюмных комплексах, встречается немало изображений представителей иных этносов: поляков, албанцев, «малороссиян» (украинцев), цыган, германштадских крестьян, крымских татар, «киргизок», казанских татар, «черемис» (марийцев), вотячек (удмурток), мордовок, венгерского крестьянина, финляндской невесты, литовца, еврея и др. Данная статья посвящена изображениям представителей народов Волго-Уральского региона в графике Ф. Г. Солнцева: анализу костюмов и аннотаций к ним.

Для этнографов, предполагающих включить эти визуальные образы в список материалов по традиционному костюму народов Волго-Уральского региона, важны ответы на несколько возникающих вопросов. А именно: каковы были обстоятельства создания этих образов (т. е. сделаны ли они на основе натурных зарисовок, набросков, собственных наблюдений и впечатлений или же перерисованы с иных образцов-первоисточников)? Насколько точно они аннотированы? Постараемся на эти вопросы ответить. Анализ и атрибуция визуальных образов, уточнение обстоятельств их создания помогут использовать их в дальнейшем как иллюстративный материал в историко-этнографических исследованиях.

Большая часть «этнографических» листов выполнена в период 1830-1850 гг., когда Ф. Г. Солнцев совершал много поездок по разным городам и губерниям России. Создавая акварели, запечатлевшие комплексы традиционных костюмов, он изображал этнографические типажи чаще в полный рост, иногда объединял фигуры на листе одним сюжетом. Кроме полнофигурных изображений, Ф. Г. Солнцев создал серию «портретных», отображающих особенности только головного убора и комплекса ушных и шейных украшений. В числе таких «портретов» есть две акварели, 


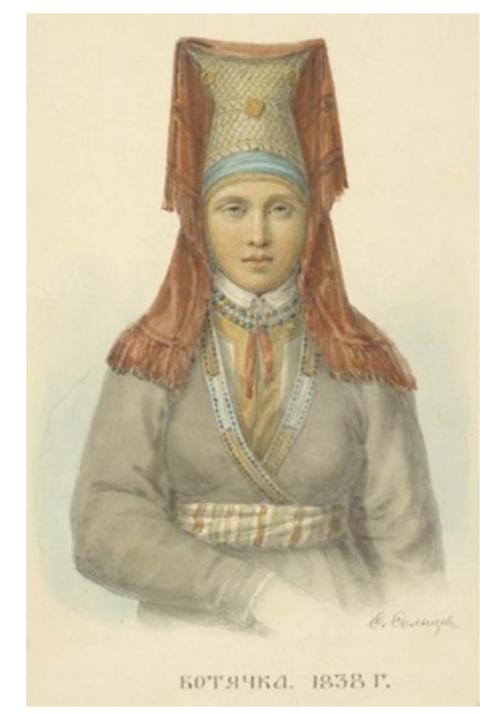

a

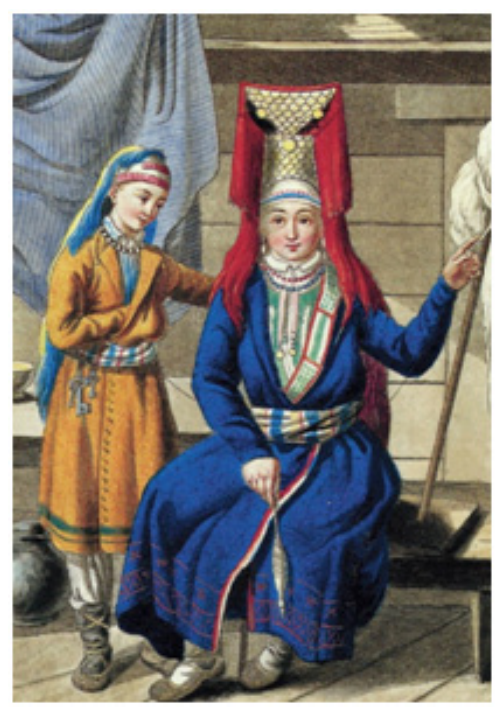

B

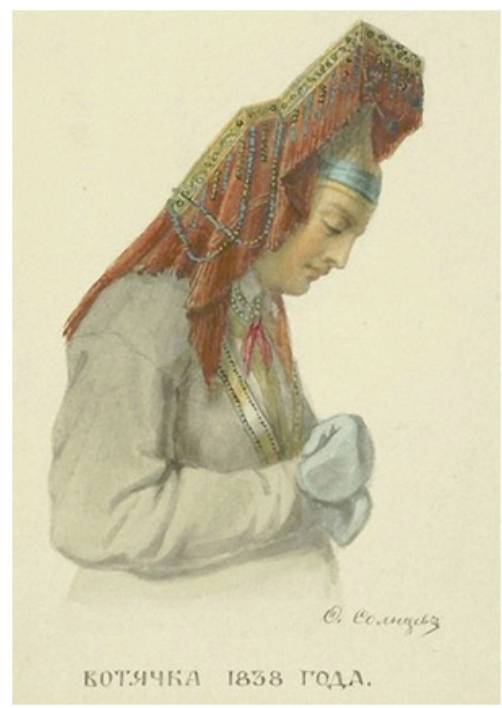

б

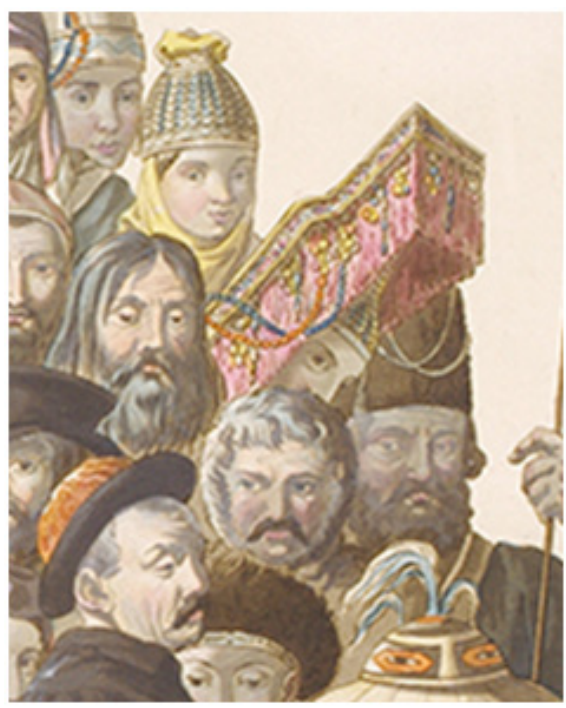

$\Gamma$

Рис.1. Акварели Ф. Г. Солнцева «Вотячка. 1838 г.» (а, б)

и гравюры Е.М. Корнеева «Вотячки» (фрагмент) (в),

«Народы, обитающие в Российской империи» (фрагмент) (г)

с аннотациями: «Вотячка» (Рис. 1 a, б), изображающими женщину-удмуртку в традиционном головном уборе - айшоне. При том что «вотячка» Ф. Г. Солнцева вписывается в круг его «портретных» образов, выполненных с натуры, и как большинство из них имеет, дату в аннотации, художник выполнил ее не по своему натурному наброску, а скопировал с уже готового изображения: заимствовал у Емельяна Михайловича Корнеева - участника экспедиции 1802 г. по Европейской части России, Сибири и Средней Азии, выполнившего множество этнографических акварельных зарисовок, которые впоследствии стали основой для подготовленного им двухтомного альбома «Народы России» (Париж, 1812 г.) [Les peoples de la Russie ... 1812]. На гравюре «Вотячки» из альбома Е. М. Корнеева изображены две фигуры в интерьере: женщина и девочка (Рис. 1 в). Женщина запечатлена в момент прядения: она сидит на лавке, на донце пряхи, в одной её руке - веретено, а другой она вытягивает нить из кудели. Над головой её - полати, на которых спит человек. На женщине-удмуртке верхняя одежда синего цвета, подпоясанная кушаком и украшенная нашивками по подолу и по краю левой полы (в верхней части до талии). На голове 
у нее высокий головной убор - айшон с покрывалом сюльк. Айшон чешуйчато зашит монетами, на их фоне выделяются размерами три крупных, две из которых нашиты в верхней части по сторонам, а одна - в центре. Самого покрывала сюлькк, лежащего на айшоне, в этом ракурсе не видно, но с верхних углов айшона свисает длинными красными нитями бахрома сюлыка, обрамляя лицо и покрывая плечи женщины. Всю композицию Е. М. Корнеева Федор Солнцев не копирует, он воспроизводит фигуру женщины и только до талии, сохраняя при этом многие детали: у «вотячки» Ф. Г. Солнцева, так же, как и у Е. М. Корнеева, рубаха на женщине изображена с маленьким отложным воротником, центральный её разрез обрамлен неширокими желтыми полосками (очевидно, вышивки), под воротничком - две нитки бус из круглых бусин; на кушаке изображены поперечные синие и красные полоски, на фоне чешуйчатой зашивки поверхности айшона также выделяются три крупные монеты (расположенные в тех же местах); воспроизводится даже положение правой руки, согнутой в локте. Различия прослеживаются в цветовом решении: у Ф. Г. Солнцева цвета чуть сдержаннее.

Профильное изображение «вотячки» Ф. Г. Солнцев тоже позаимствовал у Е. М. Корнеева. На титульной странице альбома Е. М. Корнеева (1912 г.) помещена гравюра «Народы, обитающие в Российской империи», представляющая «коллективный портрет» народов. На этой гравюре компактной группой изображены представители различных народов: мужские и женские лица в профиль, в анфас и в «три четверти» (этническим маркером выступают различные головные уборы). В композиции присутствует профильное изображение женщины удмуртки. Идентифицировать её помогает айшон, высокий головной убор; лица ее почти не разобрать: оно покрыто тенью от бахромы, а в нижней части - головой другого персонажа (Рис. 1 г). Хотя лица удмуртки почти не видно, специфическая форма изображенного Е. М. Корнеевым айшона позволяет без труда узнать его на голове у «вотячки» Ф. Г. Солнцева, а именно: у Е. М. Корнеева профильный силуэт айшона имеет некий «излом», «ступень» в задней части, точно воспроизведенный Ф. Г. Солнцевым. Убранство изображенных Е. М. Корнеевым и Ф. Г. Солнцевым айшонов тоже сходно: головной убор украшен свисающими и пересекающимися нитями бус, множественными подвесками у верхнего края, выделяющимися на фоне бахромы. Есть незначительные различия этих двух профильных изображений. У Е. М. Корнеева изображена только голова (точнее - головной убор), а у Ф. Г. Солнцева (кроме лица) изображена верхняя часть корпуса и прижатые к груди руки в белых варежках; у Е. М. Корнеева взгляд удмуртки обращен на зрителя; у Ф. Г. Солнцева на красивом античном профиле удмуртки глаза кротко опущены вниз.

Продолжить галерею образов финно-угорских народов Волго-Уральского региона, созданных Ф. Г. Солнцевым, должны были два листа, аннотированные как «Черемисы» (Рис. 2 а, б). На одном из них изображены: мужчина, играющий на скрипке; женщина, стоящая спиной, и ребенок с волынкой (пузырем) в руках; а на другом - бытовая сцена: в избе за столом двое мужчин и две женщины; на столе - хлеб, стакан, блюдо. На этих акварелях мужчины и женщины изображены в традиционных одеждах: на женщинах зашитые монетами головные уборы и поясные украшения из трубочек с кистями на концах. Семейная сцена в интерьере за столом, как и музыканты, производят впечатление этнографических зарисовок, но и они сделаны Ф. Г. Солнцевым не с натуры. Основой стали многофигурные картины кон. XVIII - нач. XIX в. кисти неизвестного художника «Черемисы» (хранится в Кунсткамере) и «Чувашский праздник» (этнографический музей Казанского университета), чрезвычайно близкие между собою (Рис. 2г). Так, прообразом «черемиски», стоящей спиной, в композиции с музыкальными инструментами у Ф. Г. Солнцева является крайняя левая фигура на переднем плане картины «Чувашский праздник» - та же поза, тот же головной убор в виде шлема, зашитый монетами, то же поясное украшение, так же спинка рубахи украшена горизонтальной нашивкой красной тесьмы (Рис. 2 в).

Женщины-«черемиски», изображенные Ф. Г. Солнцевым в композиции семейного обеда, одеты в те же одежды, что и женщины на картинах: белые рубахи с такими же поперечными красными нашивками на груди, на голове у них зашитые монетами головные уборы не 


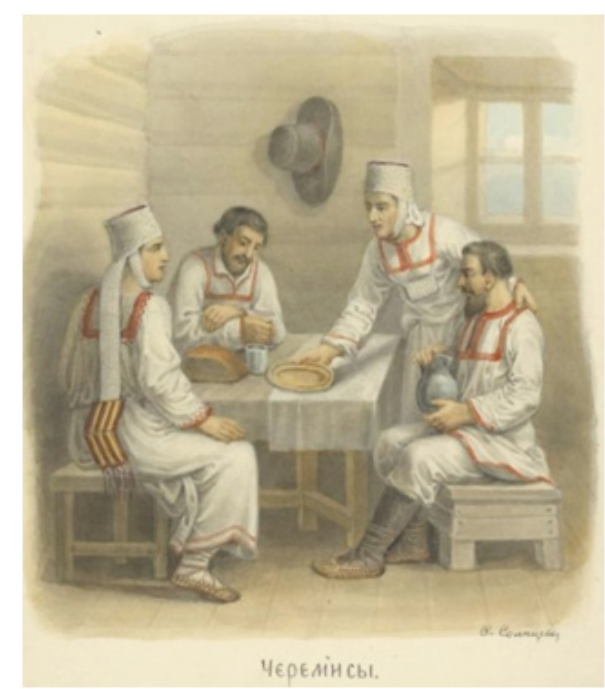

a

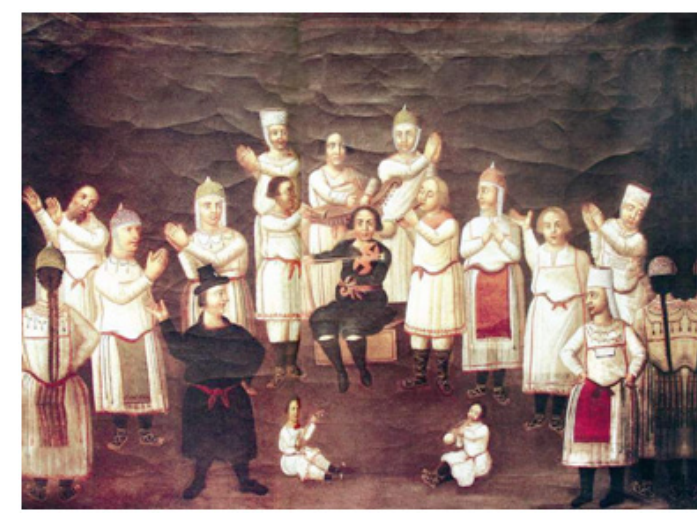

$\Gamma$

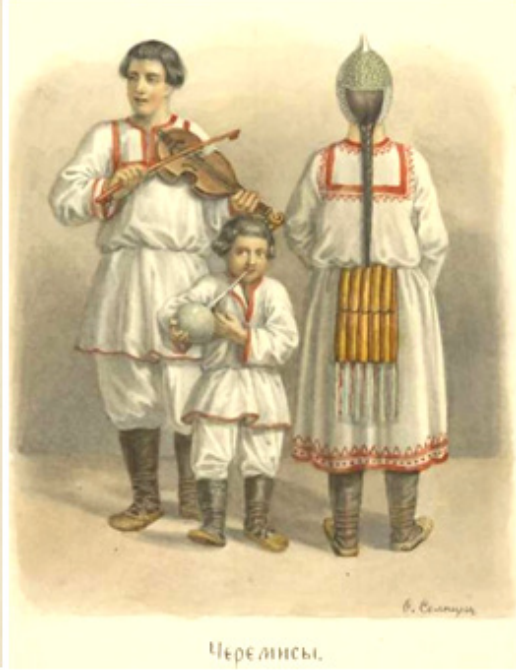

б

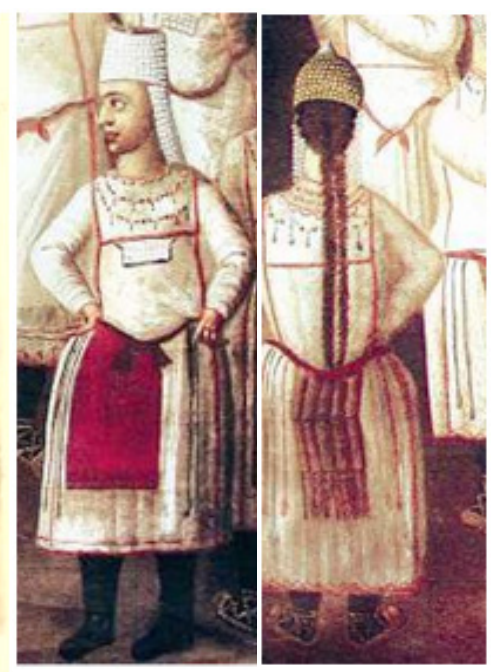

B

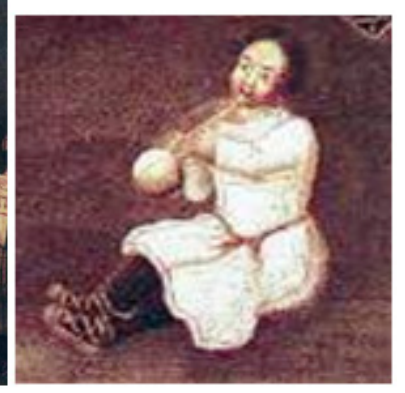

Д

Рuc. 2. Акварели Ф. Г. Солнцева «Черемисы» и картина неизвестного художникасамоучки конца XVIII начала XIX в. «Чувашский праздник» (г) и ее фрагменты (в, д).

шлемовидной формы (как у «черемиски» в только что рассмотренной композиции), а в форме цилиндра с лопастью, спадающей на спину; на груди у женщин - украшение прямоугольной формы, зашитое монетами. Одежда мужчин-«черемис» Ф. Г. Солнцева и персонажей картин тоже совпадает в своих характеристиках и деталях: вырез рубахи под горло, разрез по центру до поперечной горизонтальной нашивки, белые штаны, черные онучи и лапти.

Мальчик с волынкой на той же акварели Ф. Г. Солнцева своим прототипом имеет изображение мальчика с подобным же музыкальным инструментом на картине (Рис. 2 д). Оба изображенных Ф. Г. Солнцевым музыкальных инструмента (скрипка и пузырь) есть в сцене народного праздника на рассматриваемой картине. Не вызывает сомнения, что акварели Ф. Г. Солнцева «Черемисы» связаны своим происхождением с рассмотренными картинами. Основой для создания своих акварелей «Черемисы» он, вероятно, использовал хранящуюся в МАЭ (Кунсткамере) картину, написанную маслом («Черемисы», Инв. № 375-5). Внимательный анализ картин и особенностей костюма изображенных персонажей привели Г. Н. Иванова-Оркова к заключению, что на этих картинах изображены не марийцы, а чуваши анат-енчи или северной группы анатри [Орков 1997, 112]. Аргументы исследователя представляются убедительными: шлемообразная, с заостренной макушкой форма девичьей шапочки тухья была характерна для чувашского костюма, вышеупомянутые горизонтальные нашивки на груди - элемент, характерный для декора рубах некоторых групп чувашей [Иванов, Иванов-Орков, Иванов 2002, 262-280]. К тому же, на обороте хранящейся в Казани картины указано: «Чуваши Казанской губ., Цивильского у.» [Орков 1997, 113]. Таким образом, на акварельных листах Ф. Г. Солнцева, аннотированных как «Черемисы», изображены комплексы не марийского, а чувашского народного костюма. Основой для создания 


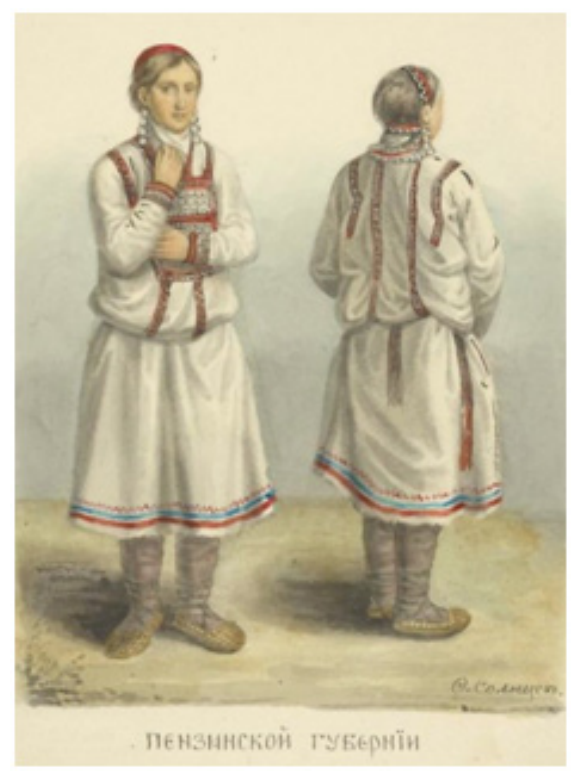

a

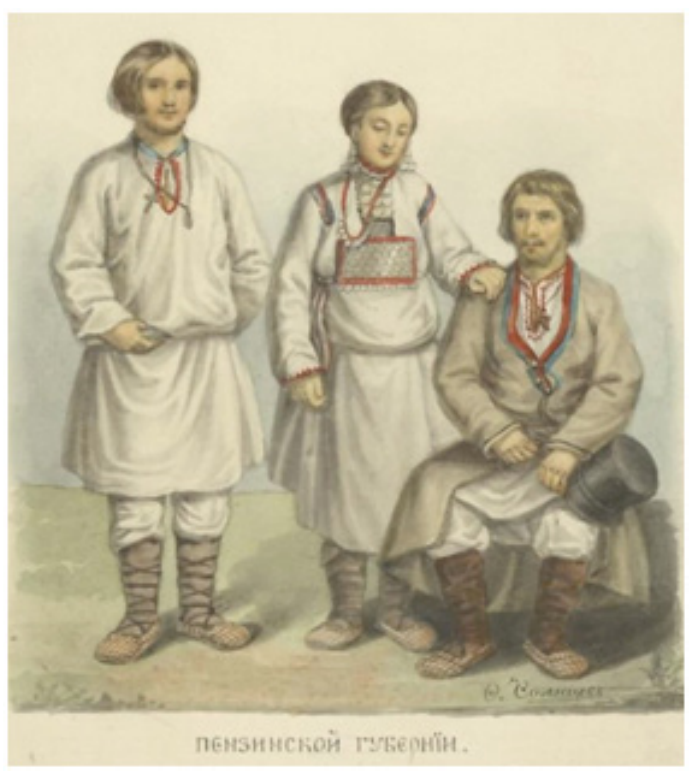

6

Рис. 3. Акварели Ф.Г. Солнцева «Пензенской губернии» (a, б)

акварелей была картина неизвестного художника-самоучки. Однако, марийская традиционная одежда всё же нашла отражение в творческом наследии Ф. Г. Солнцева.

Среди его работ, посвященных этнографическим типажам, есть листы, в аннотациях к которым указана не этническая атрибуция, а только губернии. На двух интересующих нас листах с изображением людей в традиционной одежде значится «Пензенской губернии» (Рис. 3 a, б). На одном из них - женская фигура в двух ракурсах (лицом и спиной); на другом - группа из трех человек (двое мужчин и женщина). На акварели изображена женщина в белой рубахе, носимой с напуском у пояса, на её голове, к которой сзади крепится головное полотенце, концы которого уложены вдоль спины (две вертикальные красные линии по центру спины у изображенной фигуры - это его края). Сзади из-под пояса виднеется конец приплетаемого к косе украшения. На груди женщины прямоугольные пластины, зашитые монетами; в ушах - украшения из монет, а на ногах - черные онучи с лаптями. Изображенный костюмный комплекс указывает на близость его к традициям верховых чувашей и горных мари, которые, в свою очередь, близки между собой. Однако есть детали, позволяющие определить запечатленный костюм как марийский. В составе украшений изображенной женщины есть свисающий от подбородка на грудь элемент: небольшой прямоугольный нагрудник, зашитый монетами (расположенными в три вертикальных ряда). Подобные украшения известны в составе марийского костюма (например, «ама», «ариам», «онйолва» луговых марийцев) [Молотова 1992, 44; Меджитова 1985, 53, 62, 63; Manninen 1957, 164, Abb 186 b]. Помимо этого, на изображении женских фигур отсутствует передник, тогда как в чувашском женском костюме этот предмет был практически обязательным элементом, к тому же весьма старинным (наиболее древние экспонаты в музейных фондах датируются XVIII в.). В марийский костюм передник проникает сравнительно поздно, по мнению Т. Л. Молотовой, «не раньше второй половины XIX века» [Молотова 1992, 33]. На фотографиях нач. XX в. марийки (девушки-подростки, женщины) не всегда в фартуках. Тот факт, что марийцы не проживали в Пензенской губ., а чуваши стали расселяться в тех местах уже в XVIII в., не доказывает принадлежности изображенного костюма чувашам. Одежда чувашей Пензенской губ. относится к костюмному комплексу саратовских чувашей [Иванов-Орков 2002, 218]. Пензенские чуваши имели яркий самобытный костюм, разительно отличавшийся от изображенного [Иванов-Орков 2005]. Вероятнее всего, Ф. Г. Солнцев изобразил горномарийский костюм (головная повязка нашмак и головное полотенце, которое закрывает шею и спускается по спине шарпан, ушные украшения, на груди пластина, 


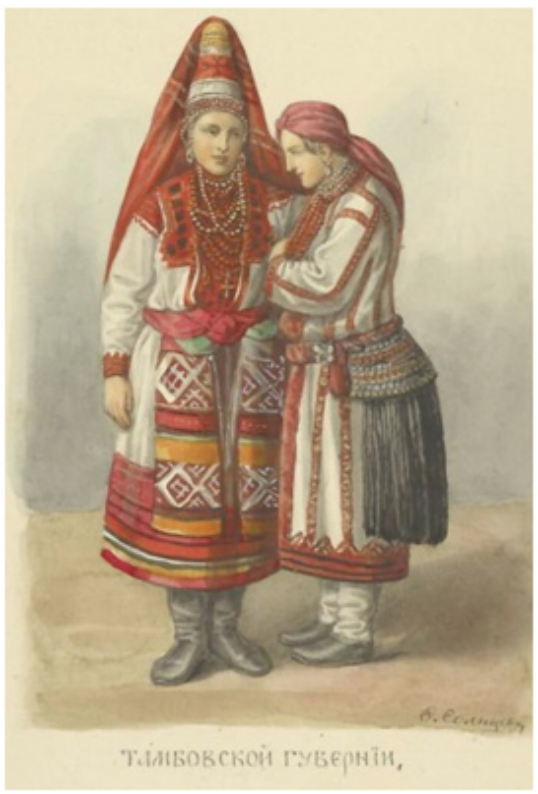

Рис. 4. Акварель Ф. Г. Солнцева «Тамбовской губернии»

зашитая монетами - ширкама). Аннотация под акварелью «Пензенской губернии», очевидно, для изображенного комплекса одежды ошибочна, что в географической привязке и в отсутствии этнической атрибуции, вероятно, стало следствием того, что и это изображение не было сделано Солнцевым с собственного натурного рисунка.

На другом листе художника, подписанном тоже без этнической атрибуции персонажей с указанием «Тамбовской губернии» (Рис. 4), изображены две женщины, по одежде которых в них несложно узнать мордву-эрзю. Но в Тамбовской губ. проживала преимущественно мордва-мокша; лишь на северо-западе в Темниковском уезде Тамбовской губ. существовала группа мордвы-эрзи, со своими специфическими чертами в одежде и в ее отделке, не позволяющие соотнести ее с изображенными костюмами.

На мордовке - высокий головной убор с каркасом из луба панго [Белицер1973, 148-149; Прокина, Сурина 1990, 48; Heikel 1899, T. CXV]. На красном фоне в центральной части убора можно рассмотреть (очевидно, вышитый) орнамент прямой крест с развилками на концах (эрзянский панго украшался вышивкой). Поверх панго накинуты красный распущенный платок или фата. Женщина мордовка изображена в верхней одежде руия. Руц̧я у эрзянки Ф. Г. Солнцева подпоясана кушаком, длинные, свисающие концы которого украшены контрастным геометрическим орнаментом из крупных ромбов. Поверх руции эрзянки носили передник икельгапаця, украшенный подобными узорами [Белицер 1973, 181; Прокина, Сурина 1990, 42]. Вероятно, художник ошибся, приняв передник на изображении, которое послужило основой для создания его акварели, за узорные концы кушака. Грудь изображенной мордовской женщины украшают белые и красные бусы, на нити бус - крупный крест. У мордвы существовала традиция носить гайтаны (ожерелья с крестом) хрёст ведьме [Белицер 1973, 124].

Вероятнее всего, на акварели Ф. Г. Солнцева изображена невеста или молодуха. По традиции невеста должна была быть в руцฺе. Руия - праздничная, ритуальная одежда. У праздничной руци подол богато декорировали (как на акварели Ф. Г. Солнцева). Подвенечная руцяя (венчама руия) отличалась богатством украшений и вышивок. Головной убор панго впервые надевали на свадьбе или спустя некоторое время после нее [Белицер 1973, 149], местами «было принято покрывать невесту поверх панго распущенным платком или фатой» [Белицер $1973,149]$, как изображено у Ф. Г. Солнцева.

Анализ изображенного на невесте-эрзянке костюма показывает, что он принадлежит восточной группе эрзи [Белицер 1973, 179-181; Прокина, Сурина 1990, 36-49; Heikel 1899, T. CXV, CXVIII]. Для этого комплекса были характерны и высокий каркасный головной убор панго, и руця, по своим характеристикам относящаяся к 1 типу (по В. Н. Белицер): ее рукава «не имели продольной вышивки, только на концах была довольно широкая вышивка того же типа, что и на груди», и «имела богатый «наряд» (петькс) на подоле из лент, полосок бархата, блесток и мишуры» [Белицер 1973, 83-84]. Этот тип бытовал на территории б. Симбирской губ. (восточных и юго-восточных районов Мордовской АССР и Чувашской АССР). Праздничная руия могла там подпоясываться широким красным кушаком (как и на акварели), а ее грудь могла украшать вышивка вдоль пол с небольшими темными квадратными ячейками (как на изображении Ф. Г. Солнцева) [Прокина Сурина1990, 50-51, 54]. Ее носили с передником, который украшали широкие полосы с контрастным (красно-белым) геометрическим орнаментом, в основе которого - крупные ромбы [Прокина, Сурина 1990, 43, 59]. Перечисленные особенности находят соответствия также в рассматриваемом изображении. 


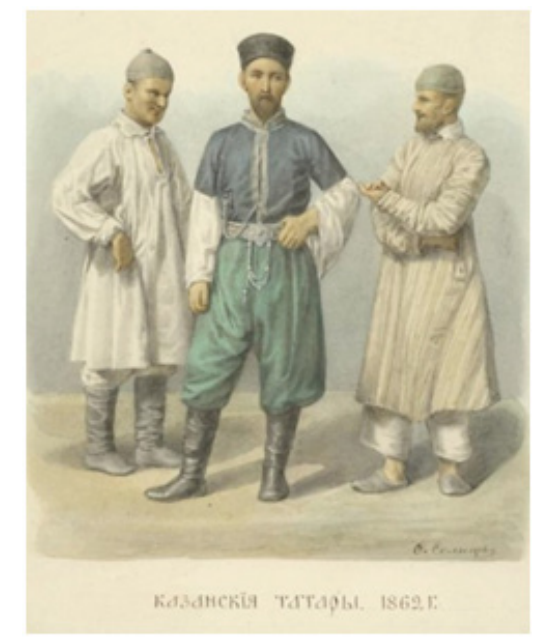

a

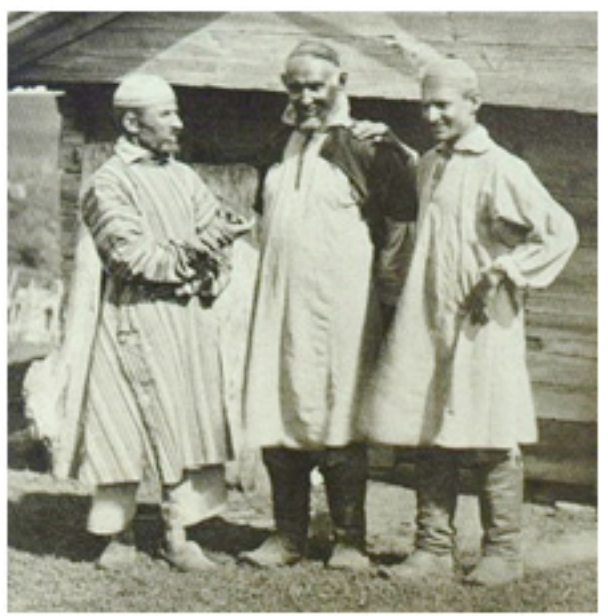

B

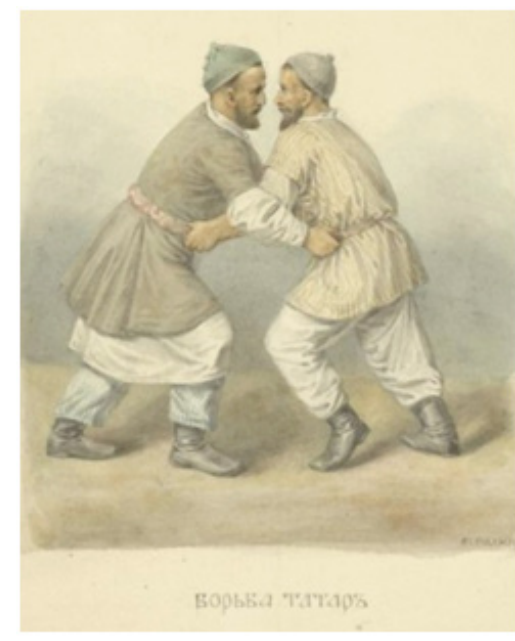

6

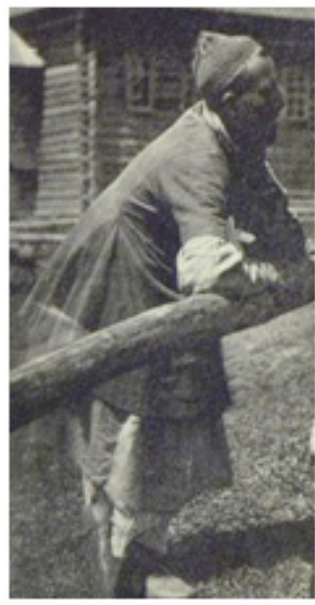

$\Gamma$

Рис. 5. Акварели Ф. Г. Солнцева «Казанские татары. 1862 г.» (а), «Борьба татар» (б) и фотографии татар-мишарей

Симбирской губернии В. Каррика (в, г - фрагмент)

Рядом с невестой-эрзянкой на акварели Ф. Г. Солнцева - женская фигура в красном платке, в белой рубахе и в набедренном украшении пулай (пулагай), которое эрзянские девушки и женщины носили поверх рубахи. У этого украшения очень длинная черная бахрома, напоминающая украшения, бытовавшие у восточной группы эрзи [Прокина, Сурина 1990, 56; Heikel 1899, CXVII (3)], т.е. костюм изображенной справа женщины относится к тому же костюмному комплексу, что и костюм «невесты».

Среди этнографических типов, запечатленных Ф. Г. Солнцевым, есть изображения татар. На листах, датированных 1830 г., аннотированных как «Татары» («татарин», «татарская девушка», «татарская женщина»), запечатлены образы крымских татар. На одном листе Ф. Г. Солнцев указывает первоисточник созданного им образа: «Татарин. С чертежа Д:Т:С:А:Н Оленина. 1831 г.». Только 4 листа Ф. Г. Солнцева имеют аннотацию «Казанские татары». На одном из них изображена группа из трех стоящих мужчин (Рис. 5 a). На боковых фигурах - повседневные светлые одежды: длинная широкая рубаха и штаны, верхняя одежда с запа́хом, шапочка тубәтәй. На их фоне центральная фигура словно выпадает из группы и смотрится чужой, не органичной: комплект ее одежды вызывает ассоциации не с казанскими татарами, а с крымскими. Такое соединение в одной группе людей в различных костюмных комплексах было возможно, если эта композиция является не натурной зарисовкой, а комбинацией готовых обра- 
зов. Их поиск дал несколько неожиданный результат. Ф. Г. Солнцев в своей акварели воспроизвел группу из трех мужчин, заимствованную у Вильяма Каррика - фотографа, сделавшего много фотографий русских крестьян, мордвы, чувашей и татар во время своего путешествия по Симбирской губ. [Вильям Каррик... 2010, 142] (Рис. 5 в). Художник их воспроизвел, но в зеркальном отражении и с заменой центральной фигуры (в оригинале в центре - пожилой мужчина с тюбетейкой на голове, одетый, так же, как и рядом стоящие мужчины, в длинную широкую рубаху). На другой акварели Ф. Г. Солнцева, посвященной казанским татарам, изображен традиционный вид мужской борьбы тюркских народов - куреш: борющиеся мужчины, держащие друг друга за пояс (Рис. 5 б). Борец слева своей позой и силуэтом чрезвычайно близко соответствует фигуре татарина, облокотившегося на низкую перекладину с другой фотографии В. Каррика [Вильям Каррик... 2010, 143] (Рис. 5 г). Ф. Г. Солнцев незначительно отредактировал оригинал, а именно: чуть изменил положение ног (в оригинале видна лишь одна нога) и добавил кушак. Соперник борца - почти полное его отражение. Женский костюм татар мы можем увидеть в композиции «Казанские татарки» (Рис. 6 б): Ф. Г. Солнцев изобразил двух женщин в полотенчатых головных уборах maстар и в длинных, широких рубахах: одну из них в длинном камзоле и кожаной обуви, другую - в лаптях. В центре композиции - мальчик. Ведущий специалист по традиционному костюму татар С. В. Суслова определила изображенный Ф. Г. Солнцевым комплекс как мишарский, отнеся его к западному культурному ареалу (центральной зоне). Географически эта зона охватывала уезды Рязанской, Тамбовской, Пензенской, Саратовской и частично Симбирской губерний с компактным проживанием чокающих мишарей [Суслова 2018, 171, 174, 176]. Женские образы в подобных одеждах также можно увидеть

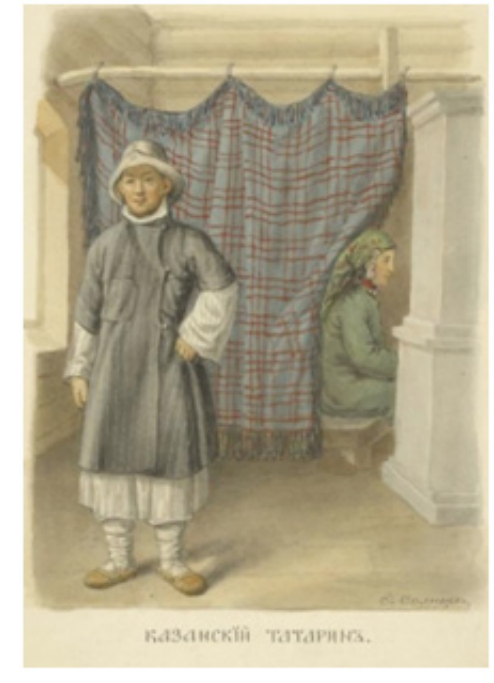

a

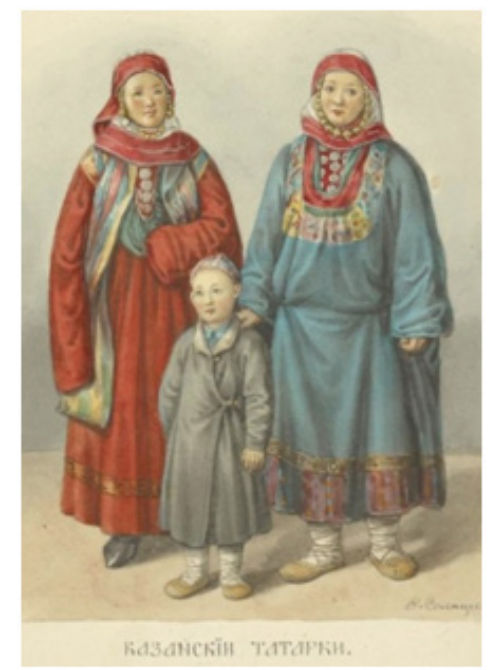

б

Pис. 6. Акварели Ф. Г. Солнцева «Казанский татарин» (а), «Казанские татарки» (б)

на фотографиях Вильяма Каррика, но ни одна из опубликованных фотографий не имела точных соответствий этой акварели Ф. Г. Солнцева и не могла служить основой для ее создания.

Акварель «Казанский татарин» представляет собой фигуру в традиционном интерьере (Рис. 6 а). Мужчина в белой шляпе и в лаптях одет в длинную белую рубаху и в застегнутый на все пуговицы темный (в тонкую светлую полоску) длинный камзол с рукавами до локтей. Из деталей интерьера в «кадр» попадают: край окна (слева), на заднем плане - угол печи (справа) и клетчатый (очевидно, пестрядинный) занавес шаршау. Между печью и занавесом видна сидящая женская фигура. Ее лицо от висков обрамляет монетное украшение. Очень похоже, что в этой композиции изображен тот же комплекс татарского костюма. Прообразы типажей этой акварели мне не известны, возможно, что первоисточниками служили тоже фотографии. 


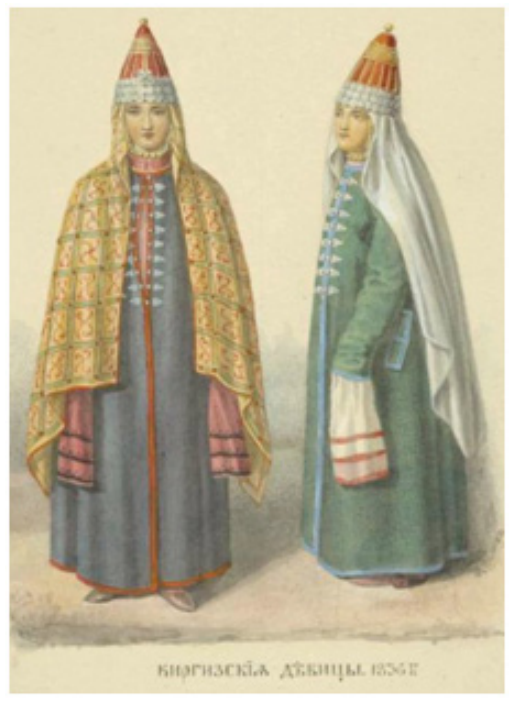

a

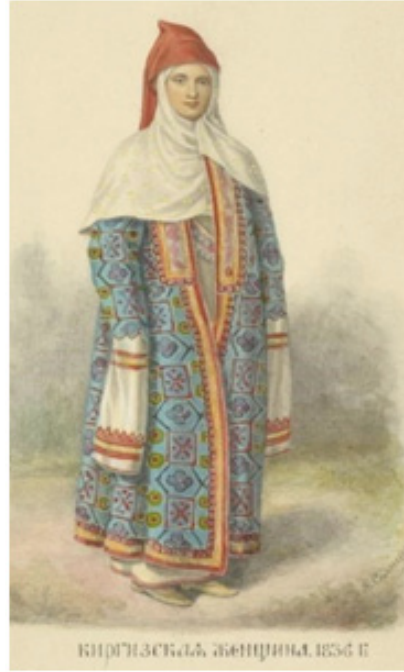

6

Рис. 7. Акварели Ф. Г. Солнцева «Киргизские девицы. 1836 г.» (а), «Киргизская женщина. 1836 г.» (б)

Признание в качестве основы для двух, по крайней мере, изображений Ф. Г. Солнцева («Борьба татар» и «Казанские татары. 1862 г.») фотографий В. Каррика позволяет уточнить место создания оригинала и, соответственно, точно определить изображенный комплекс. На фотографиях В. Каррика, а следом - на акварелях Ф. Г. Солнцева изображен комплекс одежды симбирских мишарей. Фотограф В. Каррик путешествовал и работал в Симбирской губ. в 1871, 1875 г. В свете сказанного вызывает большое недоумение дата «1862 г.», указанная в аннотации к акварели Ф. Г. Солнцева и выполненной на основе фотографии В. Каррика.

Среди работ художника можно встретить также изображения татарского женского костюма к. XVIII - нач. XIX в., заимствованные у А. Е. Мартынова, но неверно аннотированные как «Киргизские девицы. 1836 г.», «Киргизская женщина. 1836 г.» [Суслова 2018, 73, 51] (Рис. 7 а, б).

Сравнивая рассмотренные акварели Ф. Г. Солнцева с другими его этнографическими типажами, можно заметить их некоторые отличия. «Этнографические» его листы почти всегда датированы (иногда на листе присутствуют две даты, как, например, ряд типажей из Тверской губ. в аннотации имеют 1830 и 1833 годы; возможно, одна указывает время создания натурной зарисовки, а другая - год создания белового рисунка). Среди изображений традиционных костюмов народов Волго-Уральского региона даты присутствуют не на всех листах (лишь на 5 из 13): на листах с портретом «вотячки» (удмуртки) в аннотации присутствует дата (1838 г.), на листах с «киргизскими» девушками - дата (1836 г.), на акварели «Казанские татары» указана дата (1862 г.), не соответствующая ни времени создания фотографии-оригинала, ни тем более прорисовки с нее.

Ф. Г. Солнцев, фиксируя особенности традиционного костюма, изображал человеческую фигуру в полный рост и очень часто в двух или трех ракурсах (лицом и спиной / лицом, спиной и в профиль), как настоящий этнограф. Ни один из костюмных комплексов народов ВолгоУральского региона не показан им в трех ракурсах, поскольку он копировал готовые визуальные образы, их одежду, позы. Вероятным следствием того, что его акварели, изображающие костюмы народов региона, были созданы не на основе собственных натурных зарисовок, а в результате копирования иных материалов (картин, гравюр и фотографий), явилось большое количество неточностей в аннотациях и самих изображениях. Например, как мы уже отмечали, неверно была указана географическая привязка (Пензенская, Тамбовская губернии), этническая принад- 
лежность (чуваши обозначены как «черемисы» (марийцы), татарские женщины как «киргизские» (казахские), компанию мишарям в одной из композиций составил крымский татарин, в костюме мордвы-эрзи передник с крупным орнаментом превращен в узорные концы кушака.

Проведенное исследование показало, что в творчестве известного русского художникаисторика, этнографа Ф. Г. Солнцева нашли отражение этнические традиции многих народов Волго-Уральского региона: удмуртов, марийцев (горных), мордвы (эрзи), чувашей (средненизовых), татар (мишарей). Акварели Ф. Г. Солнцева, запечатлевшие традиционный костюм народов Волго-Уральского региона, - не первоисточник, но его весьма близкая к оригиналу копия и, приняв во внимание все уточнения к аннотациям его акварелей, все поправки в этническую атрибуцию, их можно использовать как иллюстрации в исследованиях традиционного костюма.

\section{ЛИТЕРАТУРА}

Белищер В. Н. Народная одежда мордвы. Труды мордовской этнографической экспедиции. Вып. III. Труды ин-та этнографии им. Н. Н. Миклухо-Маклая. Новая серия, том 101. М: Наука, 1973. 215 с.

Гатина-Шафикова Д. Ф. Визуальный образ татарского костюма в работах XVI-XVII вв. как историко-этнографический источник // Исторические, философские, политические и юридические науки, культурология и искусствоведение. Вопросы теории и практики. 2014. № 4 (42): в 2-х ч. Ч. I. C. 52-55.

Иванов-Орков Г. Н. Народный костюм пензенских чувашей // Народный костюм Пензенской губернии конца XIX - начала XX века. СПб: Пеликан, 2005. С. 308-331.

Каррик В. Картины русской жизни. Каталог выставки. СПб: СПБОО «А-Я», 2010. 218 с.

Мазанов A. А. Одежда татар XVI-XVII вв. (по старинным рисункам и гравюрам) // Новое в археологии и этнографии Татарии. Казань, 1982. С. 62-73.

Меджитова Э. М. Марийское народное искусство. Йошкар-Ола: Марийское кн. изд-во, 1985. 269 с.

Молотова Т. Л. Марийский народный костюм. Йошкар-Ола: Марийское кн. изд-во, 1992. 112 с.

Мухамедова Р. Г. Татарская народная одежда. Казань, 1997. 224 с.

Нечвалода E. E. Башкирские украшения конца XVIII в. по изобразительным материалам больших академических экспедиций // Этногенез. История. Культура. II Юсуповские чтения. Уфа, 2014. C. 189-197.

Нечвалода E. E. Изображение удмуртки и марийки в альбоме Августина Мейерберга (историкоэтнографический анализ графического источника) // Ежегодник финно-угорских исследований. 2016. Т. 1. Вып. 2. С. $125-140$.

Нечвалода E. E. Традиционная женская одежда удмуртов в материалах экспедиции Шапп де'Отроша // Ежегодник финно-угорских исследований. 2019. Т. 13. Вып. 1. С. 101-108.

Николаев В. В., Иванов-Орков Г. Н., Иванов В. П. Чувашский костюм от древности до современности. Москва-Чебоксары-Оренбург, 2002. 400 с.

Орков Г. Н. Изобразительные материалы по чувашскому народному костюму. (Графика и живопись XVIII - начала XIX вв.) // Материалы по этнографии и антропологии чувашей. Чебоксары: ЧГИГН, 1997. C. $88-117$.

Прокина Т. П., Сурина М. И. Мордовский народный костюм. Саранск: Мордов. кн. изд-во, 1990. 384 с.

Суслова С. В., Мухамедова Р. Г. Народный костюм татар Поволжья и Урала (середина XIX - начало XX вв.). Историко-этнографический атлас татарского народа. Казань: Фән, 2000. 312 с.

Суслова С. В. Татарский костюм: историко-этнологическое исследование. Казань: Татар. кн. изд-во, 2018. $239 \mathrm{c}$.

Heikel A. O. Trachten und Muster der Mordvinen. Helsingfors, 1899. $630 \mathrm{~s}$.

Lehtinen I. Tscheremissischer Schmuck. Ethnograpische Untersuchung. Helsinki, 1994. 372 s.

Les peuples de la Russie ou description des moeurs, usages et costumes des diverses nations de l'Empire de Russie, accompagnee de figures colones. Paris, D. Colas, 1812-1813. 2 v.

Manninen I. Die Kleidung // Kansatieteellinen Arkisto. B.13. Helsinki, 1957. S. 53-190. 
Нечвалода Елена Евгеньевна, кандидат исторических наук, старший научный сотрудник, Институт этнологических исследований им. Р.Г. Кузеева обособленное структурное подразделение Федерального государственного бюджетного научного учреждения Уфимского федерального исследовательского центра Российской академии наук. 6450077, Россия, г. Уфа, ул. Карла Маркса, д.6 E-mail: pishi-nikonor@yandex.ru

\section{E. E. Nechvaloda \\ PEOPLES OF THE VOLGA-URAL REGION IN FEDOR SOLNTSEV'S CREATIVE HERITAGE}

DOI: $10.35634 / 2224-9443-2020-14-4-720-732$

This paper is devoted to studying the images of the peoples of the Volga-Ural region in the graphics created by Fedor G. Solntsev, famous Russian aquarelle artist of the 19th century, the author of many historical reconstructions and ethnographic drawings of folk costumes made in different provinces of the Russian Empire and among different social classes. His gallery of images also includes the peoples of the Volga-Ural region. These are the Udmurts, Mountain Maris, Erzya Mordvins, Middle Lower Chuvashs and Mishar Tatars. Many Solntsev's watercolours that embody ethnographic characteristic types were drawn from nature. However, his images of the peoples of the Volga-Ural region are just the copies from other visual sources (pictures, gravures, photographs). As primary sources Solntsev used Emelyan Korneev's gravures (to create the image of a "Votyak woman"), William Carrick's photographs (as the basis for some images of "Kazan Tatars") and the picture of an unknown amateur artist dated back to the late 18th or early 19th centuries (to create the "Cheremis" compositions). It is not improbable that the use of other's ready-made examples and not his own ethnographic drawings resulted in some inaccuracies both in the images of the peoples of the Volga-Ural region and their annotations. There are still no prototypes found for Solntsev's images of Maris and Mordvins, but the absence of ethnic attribution in the annotations, inaccuracies in their geographical references, errors in depicting the details of the Mordvins' garments and a disconnect between their poses and the angles characteristic of Solntsev's ethnic types make it possible to suggest that the images of Maris and Mordvins in the sheets of the Penza and Tambov Provinces were also copied from ready-made pictures.

Keywords: Traditional costume, peoples of the Volga-Ural region, visual images, graphics of the $19^{\text {th }}$ century, source attribution, Fedor Solntsev, Emelyan Korneev, William Carrick, visual anthropology.

Citation: Yearbook of Finno-Ugric Studies, 2020, vol. 14, issue 4, pp. 720-732. In Russian.

\section{REFERENCES}

Belitser V. N. Narodnaya odezhda mordvy. Trudy mordovskoi etnograficheskoi ekspeditsii [Folk clothing of the Mordovians. Proceedings of the Mordovian ethnographic expedition]. Trudy in-ta ehtnografii im. N. N. MiklukhoMaklaya. Novaya seriya [Works of the N.N. Miklukho-Maklay Institute of Ethnography. New Series], vol. 101, no. 3. Moscow: Nauka, 1973. 215 p. In Russian.

William Carrick. Kartiny russkoi zhizni. Katalog vystavki [Pictures of Russian Life. Exhibition Catalogue]. St. Petersburg: A-Ya, 2010. 218 p. In Russian.

Gatina-Shafikova D. F. Vizualnyi obraz tatarskogo kostyuma v rabotakh XVI-XVII vekov kak istorikoehtnograficheskii istochnik [Visual image of the Tatar costume in the works of the XVI-XVII centuries as a historical and ethnographic source]. Istoricheskie, filosofskie, politicheskie i yuridicheskie nauki, kulturologiya i iskusstvovedenie. Voprosy teorii i praktiki - Historical, philosophical, political and legal sciences, cultural studies and art history. Issues of theory and practice, 2014, no. 4 (42), part 1, pp. 52-55. In Russian.

Ivanov-Orkov G. N. Narodnyi kostyum penzenskikh chuvashei [Folk costume of the Penza Chuvash people]. Narodnyi kostyum Penzenskoi gubernii kontsa XIX - nachala XX veka [Folk costume of the Penza province of the late $19^{\text {th }}$ and early $20^{\text {th }}$ centuries]. St. Petersburg: Pelikan, 2005, pp. 308-331. In Russian. 
Mazanov A. A. Odezhda tatar XVI-XVII vv. (po starinnym risunkam i gravyuram) [Clothing of the Tatars of the $16^{\text {th }}$ and $17^{\text {th }}$ centuries (based on old drawings and engravings)]. Novoe $v$ arkheologii $i$ etnografii Tatarii [New in the archeology and ethnography of Tatarstan]. Kazan, 1982, pp. 62-73. In Russian.

Medzhitova E. M. Mariyskoe narodnoe iskusstvo [Mari folk art]. Yoshkar-Ola: Mariyskoe knizhnoe izdatelstvo, 1985. 269 p. In Russian.

Molotova T. L. Mariyskii narodnyi kostyum [Mari folk costume]. Yoshkar-Ola: Mariyskoe knizhnoe izdatelstvo, 1992. 112 p. In Russian.

Mukhamedova R. G. Tatarskaya narodnaya odezhda [Tatar national clothes.]. Kazan, 1997. 224 p. In Russian.

Nechvaloda E. E. Bashkirskie ukrasheniya kontsa XVIII v. po izobrazitelnym materialam bolshikh akademicheskikh ekspeditsii [Bashkir jewelry of the late $18^{\text {th }}$ century based on visual materials of large academic expeditions]. Ehtnogenez. Istoriya. Kultura. II Yusupovskie chteniya [Ethnogenesis. History. Culture. 2nd Yusupov Readings]. Ufa, 2014, pp. 189-197. In Russian.

Nechvaloda E. E. Izobrazhenie udmurtki $i$ mariyki $v$ albome Avgustina Meierberga (istorikoehtnograficheskii analiz graficheskogo istochnika) [The image of the Udmurt and Mari women in the album of Augustin Meyerberg (historical and ethnographic analysis of the graphic source)]. Ezhegodnik finno-ugorskikh issledovanii [Yearbook of Finno-Ugric Studies], 2016, vol. 10, no. 2, pp. 125-140. In Russian.

Nechvoloda E. E. Traditsionnaya zhenskaya odezhda udmurtov $v$ materialakh ekspeditsii Shapp de Otrosha [Traditional women's clothing of the Udmurts in the materials of the expedition of Chappe d'Auteroch]. Ezhegodnik finno-ugorskikh issledovaniy [Yearbook of Finno-Ugric Studies], 2019, vol. 13, no. 1, pp. 101-108. In Russian.

Nikolaev V. V., Ivanov-Orkov G. N., Ivanov V. P. Chuvashskii kostyum ot drevnosti do sovremennosti [Chuvash costume from antiquity to modernity]. Moscow-Cheboksary-Orenburg, 2002. 400 p. In Russian.

Orkov G. N. Izobrazitelnye materialy po chuvashskomu narodnomu kostyumu. (Grafika i zhivopis XVIII - nachala XIX vv.) [Visual materials on the Chuvash folk costume. (Graphics and paintings of the $18^{\text {th }}$ and early $19^{\text {th }}$ centuries)]. Materialy po ehtnografii i antropologii chuvashey [Materials on ethnography and anthropology of the Chuvash people]. Cheboksary, 1997, pp. 88-117. In Russian.

Prokina T. P., Surina M. I. Mordovskii narodnyi kostyum [Mordovian national costume]. Saransk: Mordovskoe knizhnoe izdatelstvo, 1990. 384 p. In Russian.

Suslova S. V., Mukhamedova R. G. Narodnyi kostyum tatar Povolzhya i Urala (seredina XIX-nachalo $X X v v$.) [Tatars' folk costume of the Volga region and the Urals (mid-19 $9^{\text {th }}-$ early $20^{\text {th }}$ centuries)]. Istorikoetnograficheskii atlas tatarskogo naroda [Historical and ethnographic atlas of the Tatar people]. Kazan: Fen, 2000. 312 p. In Russian.

Suslova S. V. Tatarskii kostyum: istoriko-ehtnologicheskoe issledovanie [Tatar costume: Historical and ethnological research]. Kazan: Tatarskoe knizhnoe izdatelstvo, 2018. 239 p. In Russian.

Heikel A. O. Trachten und Muster der Mordvinen. Helsingfors. 1899. 630 s. In German.

Lehtinen I. Tscheremissischer Schmuck. Ethnograpische Untersuchung. Helsinki, 1994. 372 s. In German.

Les peuples de la Russie ou description des moeurs, usages et costumes des diverses nations de l'Empire de Russie, accompagnee de figures colones. Paris, D. Colas, 1812-1813. 2 v. In French.

Manninen I. Die Kleidung. Kansatieteellinen Arkisto. B. 13. Helsinki, 957. S. 53-190. In German.

Received 17.09.2020

Nechvaloda Elena Evgenievna,

Candidate of Sciences (History), Senior Researcher,

R. G. Kuzeev Institute for Ethnological Studies,

Ufa Federal Research Centre of the Russian Academy of Sciences, 6, Karl Marx St., 6450077, Russian Federation, Ufa, 6

E-mail: pishi-nikonor@yandex.ru 